\title{
Diabetes mellitus and impaired glucose tolerance in urban adult population
}

\author{
Walter Rodrigues Júnior ${ }^{1}$, Sandra Cristina Nicodemo Gaban ${ }^{1}$, Elenir Rose Jardim Cury Pontes ${ }^{2}$, Celso Correia Souza ${ }^{1}$, \\ Lilian Patussi Gimenes ${ }^{1}$, Paula Ferreira Lacerda ${ }^{1}$, Maria luiza Marques Negrisolli Cunha ${ }^{3}$, José Valério Librelotto Stefa- \\ nello II $^{1}$, Lucas Marques Brum ${ }^{1}$, Annelise Achucarro Oliveira ${ }^{1}$, Clarissa Rocha Silva ${ }^{1}$, Andrezza Louise Delmondes Ribeiro ${ }^{1}$ \\ Anhanguera University - Uniderp/MS, Campo Grande, MS, Brazil. Mestre pela FMUSP e Doutor pela UFMS \\ 2 Federal University of Mato Grosso do Sul (UFMS), Campo Grande, MS, Brazil. \\ Hospital Santa Casa de Campo Grande, Campo Grande, MS, Brazil.
}

Work carried out at the Anhanguera University - Uniderp/MS, Campo Grande, MS, Brazil.

Article received: $3 / 12 / 2013$ Accepted for publication: 8/30/2013

\section{SUMMARY}

Objective: Estimating the prevalence of diabetes mellitus (DM) and impaired glucose tolerance (IGT) in the urban population aged between 30 and 69 years in the municipality of Campo Grande, state of Mato Grosso do Sul, Brazil.

Methods: Population-based cross-sectional study conducted between October/2009 and February/2011. The investigation included the determination of fasting glucose and participants with blood glucose $\geq 200 \mathrm{mg} / \mathrm{dL}$ were considered diabetic. Nondiabetic patients, which showed blood glucose $\geq 100 \mathrm{mg} / \mathrm{dL}$ and $<200 \mathrm{mg} / \mathrm{dL}$, underwent an oral glucose tolerance test (OGTT) to investigate whether they had DM or IGT.

Results: 1.429 individuals participated in this investigation. The general prevalence, adjusted for sex and age, were: $12.3 \%$ for DM (95\%CI: 10.5 to $13.9 \%)$ and $7.1 \%$ for IGT (95\%CI: 5.7 to 8.4\%). There was a higher prevalence of DM with increasing age in people with low educational level, family history of diabetes, overweight, obesity and central obesity. Among diabetic patients ( $n=195), 25 \%$ were unaware they had the disease and were diagnosed through investigation. Among patients who already knew they had DM $(\mathrm{n}=146), 37 \%$ were unaware of the potential chronic complications.

Conclusion: This study confirms the increased prevalence of DM in Brazil and emphasizes the need for early diagnosis, as well as the importance of strict adherence to medical treatment in order to prevent its much feared complications.

Key words: diabetes mellitus, disorders of glucose metabolism, chronic disease, prevalence, lifestyle, medical care.

\section{INTRODUCTION}

Diabetes mellitus (DM) is a complex and multifactorial metabolic disorder primarily characterized by a state of chronic hyperglycemia. There are several conditions that can lead to this disease, such as autoimmune destruction of beta cells in the islets of Langerhans of the pancreas, known as type 1 DM. Nevertheless, in about $90 \%$ of cases, the cause stems from the association between obesity, insulin resistance and beta cell failure, which is called type $2 \mathrm{DM}$. Several other conditions may also lead to diabetes, such as pregnancy, some tumors and pancreatic diseases. ${ }^{1}$
There is a group in the population with blood glucose levels higher than normal, but still does not meet the laboratory diagnostic criteria of DM. This intermediate range includes individuals with impaired fasting glucose (IFG) and those with impaired glucose tolerance (IGT), confirmed by oral glucose tolerance test (OGTT). ${ }^{2}$ About $25 \%$ of the members of this group will develop diabetes in 3 to 5 years. Furthermore, there is evidence that these individuals may progress already showing the same tissue damage resulting from $\mathrm{DM}{ }^{3.4}$ 
The World Health Organization (WHO) estimates, considering all age groups, a prevalence of $2.8 \%$ of diabetics worldwide in 2000, which corresponded to $171 \mathrm{mil}-$ lion people, and predicted for 2030 an increase to $4.4 \%$, which would affect approximately 366 million people. Countries like the United States and China should double the number of diabetics in this period. ${ }^{5}$

The growth of DM should be even more intense in developing countries, specifically in the Middle East, in the sub-Saharan Africa and in India. Brazil is among the 10 countries in which the largest expansion of the disease is expected by $2030 .{ }^{5}$ The Brazilian Diabetes Society (SBD) believes that in 2012, there were close to 12 million diabetics in Brazil. ${ }^{6}$

When considering the progress of diabetes, its profound socioeconomic impact and its great potential to create serious complications in the body, extensive knowledge of epidemiological data of this disease is crucial, because only then it will be possible to develop and implement effective health actions for prevention, appropriate treatment and reduction of the huge negative financial impact of DM in terms of public spending. ${ }^{7,8}$

In this context, this research focused on estimating the prevalence of DM and IGT in the urban adult population of the municipality of Campo Grande, MS, by socioeconomic status, family history of DM and presence of overweight, obesity and central obesity. Another objective was to evaluate the profile of the study participants who already had a diagnosis of diabetes with respect to treatment adherence and knowledge of chronic complications that can arise from this disease, and also of those who had a diagnosis of DM through this study.

\section{Methods}

This cross-sectional population-based study was carried out from 10/2009 to 2/2011 by means of home visits in adults 30-69 years of age residing in the urban area of Campo Grande, capital of Mato Grosso do Sul (MS), in the Midwest region of Brazil. The city is located in the center of the state, in the hills of Maracaju, and is divided into seven urban districts (Centre, Segredo, Prosa, Bandeira, Anhanduizinho, Lagoa and Imbirussu). The population, according to the 2010 census, ${ }^{9}$ was 786.797 people, comprising $51.5 \%$ women and $48.5 \%$ men, so that $98.7 \%$ of the population lived in urban areas.

The minimum size calculated for the sample ${ }^{10}$ was 1.068 participants. Confidence interval of $95 \%$ and a prevalence of $50 \%( \pm 3 \%)$ were considered. A $30 \%$ increase was designed to cover possible losses and refusals.
Of each administrative region, around $15 \%$ of census tracts were drawn, which resulted in the selection of 103 of the 682 listed by the Brazilian Census Bureau, IBGE. The quantity of sectors was defined by operational issues, because the greater the number of sectors, the higher the demand for movement, considering a minimum of two visits per household.

In this research, a random sample was used, with two main strata for male and female genders. These broader strata included sub-strata formed by the age group of 30 to 69 years, which were divided into 5-year age intervals. Each sector had a randomly selected representative sample of individuals studied, corresponding to its population distribution and the formation of the corresponding strata and sub-strata.

After determining the residences to be investigated, visits were made in two stages. On the first visit, a clarification on the content and importance of the study was done. If the resident fulfilled the inclusion criteria, that is, being in the age group 30-69 years and accepting to take part in the study, a consent form for their participation was then signed. Pregnant women were excluded from the study, since in that case the glycemic diagnostic values are different and diabetes may be just circumstantial, disappearing after delivery.

Still on the first visit, an interview was conducted with a standardized form containing questions regarding identification (gender, age and race), socioeconomic data (monthly income and education), previous diagnosis of $\mathrm{DM}$, and whether there are any diabetics in the family. Subsequently, a second visit was made, usually the day after the first contact, in which a brief physical examination and blood glucose test measures to investigate DM or IGT were performed.

The interview, physical examination and measurement of blood glucose were made at the homes of participants and run by doctors and medicine students at Anhanguera University-Uniderp, who received training and were continuously supervised by a study coordinator.

Physical examination included weight, height, body mass index (BMI) and waist circumference (WC). Individuals with a BMI between 25 and $29.9 \mathrm{~kg} / \mathrm{m}^{2}$ were considered overweight and those over $30 \mathrm{~kg} / \mathrm{m}^{2}$ were considered obese. Male participants with WC greater than 102 $\mathrm{cm}$ and females over $88 \mathrm{~cm}$ were considered with central obesity.

Body weight was measured using portable digital scales from Tanita ${ }^{\circledast}$ brand, with a variation of $0.1 \mathrm{~kg}$ and capacity of up to $150 \mathrm{~kg}$, precisely calibrated before and du- 
ring the study. Waist circumference and height were measured using, respectively, tape measure and metallic tape by Lufkin ${ }^{\circledR}$, with $0.1 \mathrm{~cm}$ variation to reach 3 meters.

The measurement of fasting capillary glucose (FCG) was performed in all participants except those with a previous diagnosis of DM confirmed by laboratory tests and prescription of insulin or oral hypoglycemic agent. The individuals were instructed at the first visit to fast for 10 to 12 hours for measurement of blood glucose in the morning. Lancets and disposable test strips were used for the procedure, and the Accu-Chek Performa glucose meter $\left(\right.$ Roche $^{\circledR}$ ) for measurement of glucose, which has immediate readings ( 5 seconds) and dosage range of blood glucose 10 to $600 \mathrm{mg} / \mathrm{dL}$. These monitors were calibrated and tested before the study and then every 15 days during its usage.

Those who had fasting glucose $<100 \mathrm{mg} / \mathrm{dL}$ in the investigation were normal and blood glucose $\geq 200 \mathrm{mg} / \mathrm{dL}$, diabetic. Individuals with a fasting blood glucose levels $\geq 100$ and $<200 \mathrm{mg} / \mathrm{dL}$, in turn, like $1 / 6$ of those with normal glucose were subjected to an OGTT. ${ }^{11}$ In this test, the blood glucose was measured at 2 hours after ingestion of 75 $\mathrm{g}$ anhydrous glucose dissolved in a glass of water. Individuals who had blood glucose $<140 \mathrm{mg} / \mathrm{dL}$ were considered normal, those with glucose $\geq 140$ and $<200 \mathrm{mg} / \mathrm{dL}$, with IGT and those with a blood glucose $\geq 200 \mathrm{mg} / \mathrm{dL}$ were diagnosed as diabetic.

To calculate the adjusted overall prevalence of DM and IGT, the population census of 2010 was used as a standard. ${ }^{9}$ The standard population, we obtained the weights expressed by the proportions of individuals in each age group and gender, which were applied to the prevalence of diabetic individuals.

To compare proportions, we used Chi-square $\left(\chi^{2}\right)$ test. Prevalence ratios were calculated with respective confidence intervals of $95 \%$. The level of significance was $\mathrm{p}<0.05$. Statistical programs used were: Minitab 14 for Windows ${ }^{\circledR}$ (Minitab Inc., State College, Pennsylvania, USA) and Bio Estat 5.3 (Sociedade Mamirauá, Belém, Pará, Brazil).

This study was approved by the Ethics and Research Committee of Anhanguera University - Uniderp ( $n$. 119/07). All ethical precepts contained in Resolution number 196/96 of the National Health Council were followed.

\section{ResULTS}

In this study, 1.429 individuals were included, 827 (58\%) women and $602(42 \%)$ men. The mean age of participants was 47.6 years. There was $6 \%$ of loss or refusal, which is thus less than expected (30\%) in the sample calculation.

The following general prevalence for the population 30-69 years of age in the municipality of Campo Grande/ MS were estimated: for DM, the unadjusted prevalence was $13.7 \%$, and the adjusted prevalence by sex and age group, $12.3 \%$ (95\% CI: 10.5 to $13.9 \%$ ); for IGT, unadjusted prevalence was $7.3 \%$ and adjusted prevalence was $7.1 \%$ (95\% CI: 5.7 to $8.4 \%$ ). The unadjusted prevalence by sex and age group, and overall adjusted prevalence of DM and IGT are described in table 1.

TABLE 1 Unadjusted and adjusted prevalences of diabetes mellitus (DM) and impaired glucose tolerance (IGT), by sex and age group, in the population of Campo Grande, MS

\begin{tabular}{|c|c|c|c|c|c|c|c|c|c|}
\hline \multirow[t]{2}{*}{ Variables } & \multicolumn{3}{|c|}{ Women $(n=827)$} & \multicolumn{3}{|c|}{ Men $(n=602)$} & \multicolumn{3}{|c|}{ All $(n=1.429)$} \\
\hline & $\mathrm{n}$ & $\%$ & Total & $\mathrm{n}$ & $\%$ & Total & $\mathrm{n}$ & $\%$ & Total \\
\hline \multicolumn{10}{|l|}{ DM } \\
\hline 30 to 39 years & 9 & 3.8 & 237 & 11 & 5.2 & 213 & 20 & 4.4 & 450 \\
\hline 40 to 49 years & 27 & 11.0 & 245 & 17 & 10.1 & 168 & 44 & 10.7 & 413 \\
\hline 50 to 59 years & 36 & 19.0 & 189 & 20 & 17.4 & 115 & 56 & 18.4 & 304 \\
\hline 60 to 69 years & 40 & 25.6 & 156 & 35 & 33.0 & 106 & 75 & 28.6 & 262 \\
\hline Unadjusted prevalence & \multicolumn{3}{|c|}{$13.5 \%$} & \multicolumn{3}{|c|}{$13.8 \%$} & \multicolumn{3}{|c|}{$13.7 \%$} \\
\hline Adjusted prevalence & \multicolumn{3}{|c|}{$12.1 \%$} & \multicolumn{3}{|c|}{$12.6 \%$} & \multicolumn{3}{|c|}{$12.3 \%$} \\
\hline \multicolumn{10}{|l|}{ IGT } \\
\hline 30 to 39 years & 10 & 4.2 & 237 & 10 & 4.7 & 213 & 20 & 4.4 & 450 \\
\hline 40 to 49 years & 14 & 5.7 & 245 & 11 & 6.5 & 168 & 25 & 6.1 & 413 \\
\hline 50 to 59 years & 22 & 11.6 & 189 & 13 & 11.3 & 115 & 35 & 11.5 & 304 \\
\hline 60 to 69 years & 7 & 4.5 & 156 & 17 & 16.0 & 106 & 24 & 9.2 & 262 \\
\hline Unadjusted prevalence & \multicolumn{3}{|c|}{$6.4 \%$} & \multicolumn{3}{|c|}{$8.5 \%$} & \multicolumn{3}{|c|}{$7.3 \%$} \\
\hline Adjusted prevalence & \multicolumn{3}{|c|}{$6.3 \%$} & \multicolumn{3}{|c|}{$8.0 \%$} & \multicolumn{3}{|c|}{$7.1 \%$} \\
\hline
\end{tabular}


Regarding gender, there was no statistically significant difference $(p=0.894)$ in the prevalence of DM among men (13.8\%) and women (13.5\%) (Table 2). However, there was a progressive and significant increase in the prevalence of DM with increasing age, regardless of sex, from $4.4 \%$ for people between 30 and 39 years of age to $28.6 \%$ in the range of 60 to 69 years, i.e., a 6.5 -fold increase (tables 1 and 2 ).

This study verified that those individuals with less education have significantly higher frequency of DM compared to those with higher educational achievement $(p<0.001)$. Nevertheless, no significant difference was observed when the presence of DM was correlated with the monthly income of the participants $(p=0.161)$ and ethnicity $(\mathrm{p}=0.443)$ (table 2$)$.
It was found that, among participants who had first-degree relatives with diabetes, there was a significantly higher prevalence of DM compared to those without kinship ( $p<0.001)$. The research also showed a statistically significant difference in the correlation between DM and overweight, obesity and central obesity $(\mathrm{p}<0.001)$ (table 2).

Of the total number of diabetics ( $n=195), 25 \%$ were unaware they had the disease, being diagnosed during the study (26\% for fasting glucose and $74 \%$ by OGTT). Considering the following four factors: age greater than 50 years, DM family history, excess body weight or central obesity, the prevalence of DM significantly increased as the number of these risk factors also increased (table 2).

TABLE 2 Number and percentage of individuals, according to socioeconomic variables and the presence or absence of diabetes, Campo Grande, MS ( $\mathrm{n}=1.429)$

\begin{tabular}{|c|c|c|c|c|c|c|}
\hline \multirow[t]{3}{*}{ Variables } & \multicolumn{4}{|c|}{ Diabetes } & \multirow{3}{*}{$\begin{array}{l}\mathrm{PR}^{(1)} \\
(95 \% \mathrm{IC})\end{array}$} & \multirow[t]{3}{*}{$P$} \\
\hline & \multicolumn{2}{|c|}{ Yes $(n=195)$} & \multicolumn{2}{|c|}{ No $(n=1234)$} & & \\
\hline & $\mathrm{n}$ & $\%$ & $n$ & $\%$ & & \\
\hline \multicolumn{7}{|l|}{ Gender } \\
\hline Female & 112 & 13.5 & 715 & 86.5 & 1 & (2) 0.894 \\
\hline Male & 83 & 13.8 & 519 & 86.2 & $0.98(0.75$ to 1.28$)$ & \\
\hline \multicolumn{7}{|l|}{ Age } \\
\hline 60 to 69 years & 75 & 28.6 & 187 & 71.4 & 1 & \\
\hline 50 to 59 years & 56 & 18.4 & 248 & 81.6 & $1.55(1.15$ to 2.11$)$ & (3) $<0.001$ \\
\hline 40 to 49 years & 44 & 10.7 & 369 & 89.3 & 2.69 (1.92 to 3.77$)$ & \\
\hline 30 to 39 years & 20 & 4.4 & 430 & 95.6 & $6.44(4.03$ to 10.30$)$ & \\
\hline \multicolumn{7}{|l|}{ Monthly income } \\
\hline No data & 1 & 50.0 & 1 & 50.0 & - & \\
\hline Up to 2 minimum wages & 92 & 15.9 & 487 & 84.1 & 1 & (3) 0.161 \\
\hline From 2.1 to 5 minimum wages & 59 & 11.2 & 467 & 88.8 & 1.42 (1.04 to 1.92$)$ & \\
\hline More than 5 minimum wages & 43 & 13.4 & 279 & 86.6 & 1.19 (0.85 to 1.66$)$ & \\
\hline \multicolumn{7}{|l|}{ Education } \\
\hline Incomplete primary education & 102 & 18.3 & 456 & 81.7 & 1 & \\
\hline Primary education & 27 & 10.3 & 234 & 89.7 & $1.77(1.19-2.63)$ & (3) $<0.001$ \\
\hline High school & 49 & 12.4 & 345 & 87.6 & $1.47(1.07-2.01)$ & \\
\hline Undergraduate & 17 & 7.9 & 199 & 92.1 & $2.32(1.42-3.79)$ & \\
\hline \multicolumn{7}{|l|}{ Race } \\
\hline No data & - & - & 1 & 100.0 & - & \\
\hline White & 115 & 14.3 & 691 & 85.7 & 1 & (2) 0.443 \\
\hline Non white & 80 & 12.9 & 542 & 87.1 & 1.11 (0.85 to 1.45$)$ & \\
\hline \multicolumn{7}{|l|}{ Body weight } \\
\hline Obesity & 92 & 21.6 & 333 & 78.4 & 1 & (3) $<0.001$ \\
\hline Overweight & 67 & 12.5 & 468 & 87.5 & $1.73(1.30$ to 2.31$)$ & \\
\hline Normal & 36 & 7.7 & 433 & 92.3 & $2.82(1.96$ to 4.05$)$ & \\
\hline \multicolumn{7}{|l|}{ Central obesity } \\
\hline Yes & 145 & 19.1 & 613 & 80.9 & 1 & $(2)<0.001$ \\
\hline No & 50 & 7.5 & 621 & 92.5 & 2.57 (1.89 to 3.48$)$ & \\
\hline \multicolumn{7}{|l|}{ Diabetic person in the family } \\
\hline No data & 12 & 12.2 & 78 & 87.8 & - & \\
\hline Yes & 127 & 19.9 & 511 & 80.1 & 1 & $(2)<0.001$ \\
\hline No & 56 & 8.0 & 645 & 92.0 & 2.49 (1.85 to 3.35$)$ & \\
\hline \multicolumn{7}{|l|}{ Risk factors ${ }^{(4)}$} \\
\hline Four & 57 & 40.1 & 85 & 59.9 & 1 & (3) $<0.001$ \\
\hline Three & 84 & 20.4 & 327 & 79.6 & 1.96 (1.49 to 2.59$)$ & \\
\hline Two & 32 & 8.0 & 370 & 92.0 & 5.04 (3.42 to 7.44$)$ & \\
\hline One & 18 & 5.7 & 299 & 94.3 & 7.07 (4.32 to 11.56$)$ & \\
\hline None & 4 & 2.5 & 153 & 97.5 & 15.76 (5.87 to 42.32$)$ & \\
\hline
\end{tabular}


Among participants who already had a diagnosis of DM $(\mathrm{n}=146), 6.2 \%$ were not monitored by a physician; among those who were undergoing treatment ( $n=137), 7.3 \%$ waited more than 1 year between each medical visit (table 3 ).

When the group aware of having diabetes was questioned about knowledge of the possible complications of chronic disease, $37 \%$ responded that they were unaware of any possible outcomes. Of the $63 \%$ who made references to the possible consequences of diabetes, the most cited were: blindness, lower limb amputation and kidney failure (table 3).

TABLE 3 Number and percentage of diabetic individuals, according to medical supervision and chronic complications, Campo Grande, MS (2009 to 2011)

\begin{tabular}{l|l|l|l}
\hline Variables & Partial result & $\mathbf{n}$ & \% \\
\hline Medical supervision & 146 & & \\
\hline No & & 9 & 6.2 \\
\hline Yes & & 137 & 93.8 \\
\hline Medical consultation & 137 & & \\
\hline$<3$ months & & 58 & 42.3 \\
\hline 3 to 6 months & & 58 & 42.3 \\
\hline$>6$ months to 1 year & & 11 & 8.1 \\
\hline$>1$ year & & 10 & 7.3 \\
\hline Chronic complications* & 146 & & \\
\hline Don't know & & 54 & 37.0 \\
\hline Blindness & & 92 & 63.0 \\
\hline Lower limb amputation & & 53 & 36.3 \\
\hline Kidney failure & & 48 & 32.9 \\
\hline Heart attack & & 29 & 19.9 \\
\hline Stroke & & 23 & 15.8 \\
\hline Neuropathy & & 1 & 0.7 \\
\hline
\end{tabular}

*Each diabetic could indicate one or more complications.

\section{Discussion}

There are few studies concerning the frequency of diabetes in Brazil. ${ }^{12-21}$ In addition, marked differences in methods employed and age groups surveyed make it very difficult to compare these investigations. Some studies analyzed populations as from childhood or adolescence, while others evaluated adults only. Disagreements regarding the collection of blood glucose are also considerable. While in some studies only venous blood glucose was measured, in other studies capillary glycemia was assessed and, occasionally, a blood glucose curve was performed.
This study found that the population aged 30-69 years in the urban area of the municipality of Campo Grande has a prevalence of $12.3 \%$ for DM and $7.1 \%$ for IGT. These rates of diabetes are consistent with more recent studies, such as research conducted in Ribeirão Preto, which found $12.1 \%$ of individuals in the age range of 30-69 years, ${ }^{13}$ and the work carried out in the city of São Carlos, which found $13.5 \%$ in a population from 30 to 79 years. ${ }^{14}$ These data, compared with the classic multicenter study conducted in nine Brazilian cities between 1986 and 1988 that found an average prevalence of $7.6 \%,{ }^{12}$ showed an increase in the prevalence of DM.

This study showed no significant difference in the frequency of DM between men and women. Current similarities of male and female behavior, in which sedentary lifestyles, large caloric intake, obesity and stress prevail, seem to override any genetic, hormonal or constitutional influence and both sexes are equally predisposed to the development of diabetes. However, the growth of disease prevalence with advancing age in all age groups is evident.

With aging, the events that predispose to diabetes are common, as well as little physical activity. Dysfunction of $\beta$ cells is then seen, with less insulin production, mainly due to a considerable deposition of amyloid $\beta$ in these cells, and there is still a significant increase in insulin resistance due to changes in body composition (e.g., decrease in lean body mass and increased fat mass), especially in the abdominal region. The findings in this study are consistent with other research, ${ }^{13,14}$ showing that diabetes does not favor any sex, but is considerably more prevalent with increasing age.

With regard to skin color, based on the reference of white and nonwhite individuals, the research did not find a significant relationship with diabetes. However, some authors found the opposite and said that blacks have more commonly insulin resistance, hyperinsulinemia and pancreatic failure than whites and therefore have a higher prevalence of DM and IGT. ${ }^{22,23}$

Regarding socioeconomic variables, research has shown that the lower the educational level, the higher the prevalence of DM. This finding suggests that those who have more access to knowledge are more concerned with the prevention of disease. ${ }^{13,14}$ On the other hand, this research revealed that the monthly income is not a factor that significantly interferes with the onset of diabetes, which leads to the assumption that a higher purchasing power is not necessarily a protective factor against the development of diabetes. ${ }^{14}$ 
This study showed that diabetics have more first-degree relatives with diabetes than those without the disease in the family, confirming that genetic inheritance is an important factor in the onset of diabetes. ${ }^{13}$

The predominant presence of DM in participants who are overweight and present central obesity, evidenced by increased waist circumference, demonstrates, in accordance with the opinion already well established in the scientific community, that these findings are risk factors that favor the onset of diabetes. ${ }^{2}$

The intra-abdominal visceral fat, compared to the subcutaneous adipose tissue, secretes large amounts of cytokines, such as resistin, TNF- $\alpha$ and IL-6, which come into certain cells, particularly in skeletal muscle cells, and interfere with insulin signaling, causing resistance to this hormone and predisposing to hyperglycemia and DM. ${ }^{24}$

The study also revealed that $25 \%$ of study subjects classified as having diabetes were unaware of having the disease, and this finding was also revealed in the investigation of Ribeirão Preto; ${ }^{13}$ but in the multicenter study, the rate observed was $50 \%$, while in São Carlos ${ }^{14} 15 \%$ of the participants ignored the fact that they had DM. The concern of diagnosing diabetes early aims at preventing the development of severe chronic complications that can progress silently in individuals who do not know that they have the disease. ${ }^{3,4}$

These findings reinforce the importance of indicating the screening/examination of diabetes in all persons from the age of 45 years and, before that age, when they have any risk factors for developing the disease, such as first-degree relatives with DM, high blood pressure, obesity, dyslipidemia or history of fasting hyperglycemia. ${ }^{1}$ This study found a higher prevalence of DM in individuals with overlapping predisposing factors.

Among participants who already had a previous diagnosis of DM, 6.2\% were not monitored by a doctor; $7.3 \%$ of those who did, waited over a year for a new consultation. This group of individuals is certainly more susceptible to poor control of diabetes due to the lack or poor adherence to treatment and, therefore, is exposed to its serious complications.

The investigation also showed that, among diabetic participants who knew they had the disease, $37 \%$ were unaware of the chronic complications, which may lead to less concern for the proper treatment. The consequences most cited by diabetic respondents were blindness, limb amputation and kidney failure. Cardiovascular outcomes are the leading cause of death, although they did not appear among the most mentioned answers. ${ }^{25}$ These findings show that increased population awareness about
DM in all aspects, especially in relation to its complications, is crucial.

This study, along with others conducted in recent decades, shows that the prevalence of DM is increasing considerably in Brazil. Preventive measures against the disease should be intensified, because it is only through continuous public health actions, both enlightening and effective, which modify lifestyle in large urban areas, reversing the lack of exercise and overeating, that the attempt to stop the progress of diabetes will be possible. ${ }^{26-28}$

\section{Conclusion}

This study estimated a prevalence of $12.3 \%$ for DM and $7.1 \%$ for IGT in the urban population of the municipality of Campo Grande, MS, Brazil. There was a higher prevalence of DM among people with less education, older age, obesity, increased waist circumference, and also among those who had relatives with the disease.

The data found in the survey show that $25 \%$ of the diabetics did not know they had the disease and were diagnosed during the investigation, and that approximately one third of patients who already knew they had diabetes were unaware of the potential chronic outcomes. This study confirms the increased prevalence of DM in Brazil and emphasizes the need for its early conclusion, as well as the importance of strict adherence to medical treatment in order to prevent its much feared complications.

\section{Resumo}

Diabete melito e tolerância diminuída à glicose em população adulta urbana

Objetivo: estimar a prevalência de diabete melito (DM) e a tolerância diminuída à glicose (TDG) na população urbana de idade entre 30 e 69 anos do município de Campo Grande/MS.

Métodos: estudo transversal de base populacional realizado entre 10/2009 e 2/2011. Na investigação, foi realizada a dosagem da glicemia capilar em jejum e os participantes com glicemia $\geq 200 \mathrm{mg} / \mathrm{dL}$ foram considerados diabéticos. Os não diabéticos, que apresentaram glicemia $\geq 100 \mathrm{mg} / \mathrm{dL}$ e $<200 \mathrm{mg} / \mathrm{dL}$, foram submetidos a um teste oral de tolerância à glicose (TOTG) para investigar se tinham DM ou TDG.

Resultados: nesta investigação, participaram 1.429 indivíduos. As prevalências gerais, ajustadas por sexo e faixa etária, foram: para DM de 12,3\% (IC95\%: 10,5 a 13,9\%) e para TDG de 7,1\% (IC95\%: 5,7 a 8,4\%). Houve maior prevalência de DM com o aumento da idade, em pessoas com 
baixa escolaridade, histórico de diabete na família, sobrepeso, obesidade e obesidade central. Do total de diabéti$\cos (n=195), 25 \%$ não sabiam que tinham a doença e obtiveram o diagnóstico por meio da investigação. Dos pacientes que já sabiam ter DM ( $n=146), 37 \%$ desconheciam as potenciais complicações crônicas.

Conclusão: este estudo corrobora o aumento da prevalência de DM no Brasil e enfatiza a necessidade de sua constatação precoce, bem como da importância da adesão rigorosa ao tratamento médico com o intuito de prevenir suas temíveis complicações.

Unitermos: diabete melito, transtornos do metabolismo da glicose, doença crônica, prevalência, estilo de vida, cuidados médicos.

\section{References}

1. Sociedade Brasileira de Diabetes. Diretrizes da Sociedade Brasileira de Diabetes, 2009. 3.ed. Itapevi: A. Araújo Silva Farmacêutica, 2009.

2. The Expert Committee on the Diagnosis and Classification of Diabetes Mellitus. Report of the Expert Committee on the Diagnosis and Classification of Diabetes Mellitus. Diabetes Care 1997; 20:1183-97.

3. Nathan DM, Davidson MB, DeFronzo RA, Heine RJ, Henry RR, Pratley R Impaired fasting glucose and impaired glucose tolerance: implications for care. Diabetes Care 2007; 30:753-9.

4. Souza CF, Gross JL, Gerchman F, Leitão CB. Prediabetes: diagnosis, evaluation of chronic complications, and treatment. Arq Bras Endocrinol Metab 2012; 56:275-84.

5. Wild S, Roglic G, Green A, Sicree R, King H. Global prevalence of diabetes. Diabetes Care 2004; 27:1047-53.

6. Sociedade Brasileira de Diabetes. São 12 milhões de diabéticos no Brasil Available at: http://www.diabetes.org.br/sala-de-noticias/2116-sao-12milhoes-de-diabeticos-no-brasil?format=pdf.

7. United Nations Population Division. Departament of Economic and Social Affairs. World Urbanization Prospects: 1999 Revision. New York: United Nations Populations Division, Department of Economic and Social Affairs, 1999

8. International Diabetes Federation. Economic impacts of Diabetes. 2010. Available at: http://www.idf.org/diabetesatlas/ economic-impacts-diabetes.

9. Brazilian Census Bureau IBGE. Campo Grande-MS. Census 2010: population characteristics - sample. Available at: htpp://www.ibge.gov.br/cidadesat/ link.php?codmun $=500270$

10. Luiz RR, Magnanini MMF. O Tamanho da Amostra em Investigações Epidemiológicas. In: Medronho RA, Bloch KV, Luiz RR, Werneck G (eds.) Epidemiologia. 2.ed. São Paulo: Atheneu, 2009. p.415-27.

11. Haffner SM, Rosenthal M, Mazuda HP, Stern MP, Franco LJ. Evaluation of three potential screening tests for Diabetes mellitus in a biethnic population, Diabetes Care 1984; 7:347-53.
12. Malerbi D, Franco LJ. Multicenter study of the prevalence of diabetes mellitus and impaired glucose tolerance in the urban Brazilian population aged 30-69 years. The Brazilian Cooperative Group on the Study of Diabetes Prevalence. Diabetes Care 1992; 15:1509-16.

13. Torquato MT, Montenegro Júnior RM, Viana LA, de Souza RA, Lanna $\mathrm{CM}$, Lucas JC et al. Prevalence of diabetes mellitus and impaired glucose tolerance in the urban population aged 30-69 years in Ribeirão Preto (São Paulo), Brazil. São Paulo Med J 2003; 121:224-30.

14. Bosi PL, Carvalho AM, Contrera D, Casale G, Pereira MA, Gronner MF et al. Prevalência de diabetes melito e tolerância à glicose diminuída na população urbana de 30 a 79 anos da cidade de São Carlos, São Paulo. Arq Bras Endocrinol Metabol 2009; 53:726-32

15. Duncan BB, Schmidt MI, Polanczyk CA, Homrich CS, Rosa RS, Achutti AC. Risk factors for non-communicable diseases in a metropolitan area in south of Brazil: prevalence and simultaneity. Rev Saúde Pública 1993; 27:43-8

16. Oliveira JE, Milech A, Franco LJ. The prevalence of diabetes in Rio de Janeiro, Brazil. The Cooperative Group for the Study of Diabetes Prevalence in Rio de Janeiro. Diabetes Care 1996; 19:663-6.

17. Souza LJ, Chalita FEB, Reis AF, Teixeira CL, Gicovate Neto C, Bastos DA et al. Prevalência de diabetes mellitus e fatores de risco em Campos dos Goytacazes, RJ. Arq Bras Endocrinol Metab 2003; 47:69-74

18. Costa JSD, Olinto MTA, Assunção MCF, Gigante DP, Macedo S, Menezes AMB. Prevalência de Diabetes mellitus em Pelotas, RS: um estudo de base populacional. Rev Saúde Pública 2006; 40:542-5.

19. Fidelis LC, Moreira OC, Teodoro BG, Oliveira CEP. Prevalência de diabetes mellitus no município de Teixeiras-MG. Rev Bras Ativ Fís Saúde 2009; 02:23 PM-7.

20. Lyra R, Silva RS, Montenegro Jr RM, Matos MVC, Cezar NJB, Maurícioda-Silva L. Prevalência de diabetes melito e fatores associados em população adulta de baixa escolaridade e renda do sertão nordestino brasileiro. Arq Bras Endocrinol Metab 2010; 54:560-6.

21. Andrade RCG. Prevalência de diabetes melito na comunidade nipobrasileira de Mombuca, Guatapará-SP. Arq Bras Endocrinol Metab 2011; 55:127-33.

22. Chiu M, Austin PC, Manuel DG, Tu JV. Comparison of cardiovascular risk profiles among ethnic groups using population health surveys between 1996 and 2007. CMAJ 2010; 182:E301-10.

23. Brito IC, Lopes AA, Araújo LMB. Associação da cor da pele com diabetes mellitus tipo 2 e intolerância à glicose em mulheres obesas de Salvador, Bahia. Arq Bras Endocrinol Metab 2001; 45:475-80.

24. Ribeiro Filho FF, Mariosa LS, Ferreira SRG, Zanella MT. Gordura visceral e Síndrome Metabólica: mais que uma simples associação. Arq Bras Endocrinol Metab 2006; 50:230-8.

25. Triches C, Schaan BA, Gross JL, Azevedo MJ. Complicações macrovasculares do diabetes mellitus: peculiaridades clínicas de diagnóstico e manejo. Arq Bras Endocrinol Metab 2009; 53:698-708.

26. Diabetes Prevention Program Research Group. Reduction in the incidence of type 2 diabetes with lifestyle intervention or metformin. N Engl J Med 2002; 346:393-403.

27. Tuomilehto $\mathrm{J}$ et al. Prevention of type 2 diabetes mellitus by changes in lifestyle among subjects with impaired glucose tolerance. N Engl J Med 2001; 344:1343-50.

28. Duarte CK, Almeida JC, Merker AJS, Brauer FO, Rodrigues TC. Nível de atividade física e exercício físico em pacientes com diabetes mellitus. Rev Assoc Med Bras 2012; 58:215-21. 